Substituting the values of $\bar{G}_{8}{ }^{\prime}$ and $\bar{L}$ given by (17) and (12) in the following equation

we find

$$
\bar{M}^{\prime}=\dot{\bar{G}}_{s}{ }^{\prime}-\bar{L}
$$

$$
X^{\prime}+i Y^{\prime}=G_{s}(\mathbf{I}-h)(\sin \epsilon \cdot \dot{\psi}+i \dot{\epsilon}) .
$$

Let

$$
\begin{aligned}
& A_{c}= \text { the equatorial moment of inertia of the } \\
& \text { core } \\
& A= \text { that of the earth as a whole, } \\
& H_{c}=\text { the mechanical ellipticity of the core. }
\end{aligned}
$$

According to K. Bullen (1936)

Then

$$
A_{c} / A=0.1 \mathrm{I} 2, \quad H_{c}=0.0026 .
$$

$$
h=\mathbf{I} .027 .
$$

If we denote the earth's angular velocity by $n$ and put

$$
\Omega=\omega_{1} t, \quad 2 \mathbb{C}=\omega_{2} t, \quad 2 \odot=\omega_{3} t
$$

we shall have

$$
\begin{aligned}
& \omega_{1}=-0.000146 n, \\
& \omega_{2}=+0.07300 n, \\
& \omega_{3}=+0.00547 n .
\end{aligned}
$$

The substitution of theoretical expressions for $\psi$ and $\epsilon-\epsilon_{0}$ in (I8) leads to the following equation :

$$
X^{\prime}+i Y^{\prime}=\bar{U}_{1}+\bar{U}_{2}+\bar{V}_{1}+\bar{W}_{1}
$$

in which

$$
\begin{aligned}
& \bar{U}_{1}=+0^{\prime \prime} .2 \mathrm{I} 7 \omega_{1} G_{s} e^{+i \omega_{1} t}, \\
& \bar{U}_{2}=-0.032 \omega_{1} G_{s} e^{-i \omega_{1} t} \\
& \bar{V}_{1}=+0 \text { ". } 0023 \omega_{2} G_{s} e^{+i \omega_{2} t} \text {, } \\
& \bar{W}_{1}=+ \text { o".oI } 4 \omega_{3} G_{s} e^{+i \omega_{3} t}
\end{aligned}
$$

Now let us take the values of $\psi_{a}$ and $\epsilon_{a}-\epsilon_{0}$ from our Table. Being substituted in (I5) they give:

$$
\begin{aligned}
X+i Y= & (\mathrm{I} .09+0.02 i) \bar{U}_{1} \\
& +(\mathrm{I} .09+0.13 i) \bar{U}_{2} \\
+ & (-0.43+0.83 i) \bar{V}_{1}-0.86 \bar{W}_{1} .
\end{aligned}
$$

Having regard to the uncertainties of the observed values as well as the computed values of $N$ and $h$, it is not easy to say to what extent this result is trustworthy. Nevertheless I should like to point out the following conclusions which, in my opinion, deserve some consideration:

(I) The actual magnitude of the vector $\bar{U}_{1}$, as inferred from observational data, is larger than that obtained theoretically for a rigid core;

(2) The actual directions of the vectors $\bar{V}_{1}$ and $\bar{W}_{1}$ are opposite to those for the rigid core.

At first glance these conclusions seem to contradict one another. However this contradiction vanishes under more close consideration. The observed changes of the vectors mentioned above agree in sign with that which would be expected on the theory of the dynamical effect of a liquid core. A quantitative comparison makes no sense because of the lack of accuracy of observational data.

$$
\text { REFERENCES }
$$

Bullen, K. 1936, M. N. Geophys. Suppl. 3, 5.

Fedorov, E. P. 1955, Bull. géod. Nov. Sér. No. 38, 28. . 1958, Nutation and the Forced Motion of the Earth's Pole (Kiev).

Hattori, I. T. 1947, Japanese Journ. Astr. and Geoph. 21, I43.

-. I95I, Pub. Astr. Soc. Japan 3, I26.

Morgan, H. R. I952, A. J. 57, 232.

Orlov, A. J. 1952, Astr. Circ. USSR No. 126, 19.

Uemae, Sh. 1953, Pub. Astr. Soc. Japan 4, 163.

\title{
NUTATION AND THE VARIATION OF LATITUDE
}

\author{
By HAROLD JEFFREYS \\ St. John's College, Cambridge, England
}

\begin{abstract}
A theoretical discussion by the author and R. O. Vicente uses geophysical estimates of the mechanical properties of the earth's shell and two extreme models for the core, chosen to make the mass and moment of inertia correct. The period found for the variation of latitude is in good agreement with observation. The 18.6-year nutation is in better agreement than has been found previously but is still not altogether satisfactory.
\end{abstract}

It is well known that the period of the I4monthly variation of latitude is greatly affected by the elasticity of the earth. For a rigid earth the period would be about 305 days. The actual period is rather uncertain but can be taken as 440 days with an extreme uncertainty of I5 days. The difference was for a long time our best datum on the elasticity of the earth as a whole.

Seismology has shown the earth to have a central core, with a radius of about 0.55 of that of the outside; this does not transmit transverse waves and is presumably liquid. Seismology has 
also led to rather detailed information about the elastic properties of the shell; if the rigidity at the base of the shell was continued to the center the elastic yielding in the variation of latitude would be too small and the calculated period too short, but if the core is liquid the yielding seemed likely to be enough.

The perturbations of the earth by the moon give an estimate of the mass of the moon. Given the rate of precession and this mass the ratio $(C-A) / C$ can be found, $C$ and $A$ being the principal moments of inertia. There are many periodic couples due to the sun and moon, tending to shift the earth's axis, and their effects are called nutations. The chief period is 18.6 years and tilts the axis with an amplitude of 9".207 \pm o".o03. The nutations can, however, all be calculated from the mass of the moon and $(C-A)$ $/ C$, on the hypothesis that the earth is a rigid body. The theoretical value is close to $9 " .227 \mathrm{I}$. J. Jackson (1930) was the first to insist that the difference is genuine.

Poincaré (1910) studied the effects of a fluid core and elasticity of the shell. He showed that elasticity could have little effect on the I8.6-year nutation, but that the effect of a liquid core might be considerable, as indeed Kelvin and others had already found. He had, of course, no quantitative data, and his work was largely overlooked, though part of it is reproduced in Lamb's Hydrodynamics. Application to the earth (Jeffreys 1948), assuming a rigid shell and a liquid core of the actual dimensions, showed that the fluidity of the core would shorten the free period from about 305 to 270 days, leaving more for elasticity to do to bring it up to the observed value. The 18.6-year amplitude would be reduced by about I part in 150 , which is in the right direction but too great. I found, however (Jeffreys 1949), that both effects would be reduced by elasticity of the shell.

The problem of the elastic yielding of the earth's shell is not very difficult if it is treated as homogeneous and incompressible. With the actual distribution of density and elasticity it is very difficult, involving the numerical solution of three differential equations of the second order. It was solved by H. Takeuchi (1950) who used two models proposed by Bullen, which cannot be far wrong.

R. O. Vicente and I undertook the allowance for the core in 1954 ; we made independent solutions but the results were in good agreement. Takeuchi's solution was a statical one, expressing all displacements of the shell in terms of six boundary values, but his relations will hold for periods of a day or longer. For the core it was necessary to retain the inertial terms. We used two models. In both, the mass of the core and its moments of inertia were made to agree with Bullard's theory of the figure of the earth. In one (Jeffreys and Vicente I957a) the core was treated as homogeneous and incompressible, with an extra particle at the center. In the other (Jeffreys and Vicente I957b) it was taken as having a distribution of density of the type $\rho=k_{0}-k_{1} r^{2} / a_{1}{ }^{2}$, the variation of density being taken as wholly due to compression. The truth should lie about midway between these models.

The method was to introduce pairs of Lagrangian coordinates to represent (I) a general rotation, displacing the axis, (2) normal displacements at the outer and inner boundaries, (3) a displacement of the core, linear in the coordinates, (4) and (5) two pairs of cubic terms in the coordinates for the core. These are of sufficient generality to represent any displacement of the core up to cubic terms in the coordinates, and all shell effects are represented by (I) and (2). The problem was thus reduced to a Lagrangian one of small oscillations, and the rest was arithmetic.

For both models the free period was found to be 392 days, but allowance for the ocean would raise this to about 430 days. The correcting factor for the 18.6-year nutation was -0.0036 for the central particle model and -o.ooi I for the Roche model; thus, compressibility of the core makes quite a large difference. The most probable value is about -0.0022 , which is about right. Solutions were also made for the fortnightly and semiannual nutations, and the bodily tide numbers were calculated for the corresponding tides.

The theory predicts that the effect in longitude would be greater than that in obliquity. So $\overline{f a r}$ Fedorov is the only astronomer to have tried to estimate them separately from observation. In his announcement to the I.A.U. in 1953 he found the effect in obliquity to be the larger, but in his memoir just published he no longer maintains this. This is a most valuable piece of work. (A detailed comparison will appear in the Monthly Notices.)

I very much doubt whether motions in the core can have any important effect on the general rotation of the earth. Bondi and Lyttleton found that there is much difficulty in explain- 
ing how the couple due to tidal friction can be transmitted to the core by viscosity, and there would be more difficulty for periods from 0.5 year to 3000 years. Electromagnetic coupling has been suggested, but so far as I know there has been no quantitative examination.
REFERENCES

Jackson, J. I930, $M . N$. 90, 733 .

Jeffreys, H. 1948, $M$. N. 108, 206.

. $1949, M . N$. 109, 670.

Jeffreys, H. and Vicente, R. O. I957a, $M . N$. II7, I42. $1957 \mathrm{~b}$, Ibid., 162.

Poincaré, H. 19ı, Bull. Astr. Paris 26, 32 I.

Takeuchi, H. 1950, Trans. Amer. Geophys. Union 31, $65 \mathrm{I}$.

\title{
LES RELATIONS ENTRE LES MOUVEMENTS DU POLE ET LES FLUCTUATIONS DE LA VITESSE DE ROTATION DE LA TERRE
}

\author{
PAR PAUL MELCHIOR \\ Observatoire Royal de Belgique, Bruxelles, Belgique
}

\begin{abstract}
Résumé. On expose comment on peut tenter une ample synthèse des résultats d'observations astronomiques telles que celles du mouvement du pôle et des fluctuations de la vitesse de rotation de la Terre avec des observations de caractère purement géophysique: les marées terrestres, la circulation atmosphérique générale, le retrait progressif des glaciers, etc. On ne peut espérer donner dès à présent une conclusion à chacun des problèmes soulevés par la confrontation de ces données si diverses et l'on relèvera plusieurs contradictions. L'effort accompli dans le cadre de l'Année Géophysique permettra peut-être de lever certaines d'entre-elles et de parfaire la synthèse évoquée ici.
\end{abstract}

Se proposer l'étude des anomalies que nous révèle l'observation de la rotation de la Terre, c'est aborder un problème de géophysique avec des méthodes d'investigation astronomiques. Qu'il s'agisse de l'étude des composantes du mouvement du pôle, de l'étude des fluctuations de la vitesse de rotation du globe ou de problèmes plus particuliers comme celui de la constante de nutation, l'on devra faire appel à des informations purement géophysiques (séismologie, marées terrestres notamment) si l'on veut progresser dans l'interprétation des phénomènes observés. Géophysiciens et astronomes étudient les mêmes propriétés physiques de la même planète par des voies différentes. Une synthèse riche en perspectives se prépare dans le cadre d'une doctrine commune que par analogie avec l'astronomie géodésique nous appellerions volontiers "astronomie géophysique."

Nous diviserons notre exposé sur les relations entre les mouvements du pôle et les fluctuations de la vitesse de rotation de la Terre en trois parties qui sont trois problèmes essentiellement différents au point de vue du géophysicien mais qui, dans l'observation astronomique, sont étroitement associés:

Premier problème. Relation entre la composante libre du mouvement du pôle, les fluctuations à période semi-mensuelle, mensuelle et semi-annuelle de la vitesse de rotation de la Terre, les marées terrestres, la séismologie, le relèvement isostatique.

Deuxième problème. Relation entre la composante forcée annuelle du mouvement du pôle, la fluctuation à période annuelle de la vitesse de rotation de la Terre, la météorologie et l'océanographie.

Troisième problème. Relation entre le déplacement séculaire du pôle, les variations séculaires de la vitesse de rotation de la Terre, la glaciologie.

I

I. L'étude des phénomènes de marées terrestres et l'étude du mouvement libre du pôle instantané de rotation à la surface de la Terre rentrent dans le cadre d'une seule et même théorie.

En effet, si la Terre était une Terre idéale, indéformable comme le suppose la Mécanique Céleste classique, on pourrait rendre exactement compte par le calcul des caractéristiques de ces deux phénomènes et même en établir des éphémérides. Mais les forces qui entrent en jeu produisent dans les deux cas des déformations et engendrent des tensions dans tout le globe. Ces déformations à leur tour additionnant leur effet à celui du potentiel initial modifient les caractéristiques des phénomènes. En première approximation, comme il s'agit de phénomènes à longue période vis à vis de la période de vibration propre de la Terre $\left(\mathrm{I}^{\mathrm{h}} 34^{\mathrm{m}}\right)$, on peut considérer que ces effets obéissent à la théorie statique. Ce sont donc les amplitudes des phénomènes qui sont modifiées: réduites ou augmentées suivant les manifestations du phénomène que l'on considère.

Ainsi dans le cas du mouvement du pôle, le pôle d'inertie vrai tend à se rapprocher du pôle instantané de rotation et le suit dans son mouvement; comme toute observation astronomique 